\title{
AFFINITY OF RABBIT UTERINE OESTRADIOL RECEPTOR FOR PHYTO-OESTROGENS AND ITS USE IN A COMPETITIVE PROTEIN-BINDING RADIOASSAY FOR PLASMA COUMESTROL
}

\author{
M. SHEMESH, H. R. LINDNER AND N. AYALON \\ Department of Reproduction, Veterinary Research Institute, Beth-Degan, and \\ Department of Biodynamics, The Weizmann Institute of Science, Rehovot, Israel
}

(Received 16th December 1970, accepted 12th Fuly 1971)

\begin{abstract}
Summary. The non-steroidal phyto-oestrogens, coumestrol and genistein, were able to compete with oestradiol-17 $\beta\left(\mathrm{Oe}_{2}\right)$ for binding sites on a macromolecular component of the uterine cytosol from 6-daypregnant rabbits. Binding affinity for these compounds was related to their reported oestrogenic potency: approximately one part by weight of $\mathrm{Oe}_{2}$, seventy of coumestrol and 175 of genistein produced equivalent inhibition of the uptake in vitro of $\left[{ }^{3} \mathrm{H}\right] \mathrm{Oe}_{2}$ by this uterine receptor. Biochanin-A, formononetin, 12-O-methylcoumestrol, sativol and medicagol did not significantly inhibit $\mathrm{Oe}_{2}$ binding, suggesting that free hydroxyl groups in both position 7 and $12\left(=4^{\prime}\right)$ of coumestans and isoflavones are essential for effective interaction with the oestrogen receptor. The 7- and 12-methoxy-coumestans and isoflavones tested appear to be pro-oestrogens, able to bind to the uterine receptor only after O-demethylation in vivo.

A rapid competitive protein-binding radioassay for phyto-oestrogens in the blood that makes use of the uterine cytosol receptor is described. Its useful range is 0.5 to $40 \mathrm{ng}$ for coumestrol and 2.5 to $200 \mathrm{ng}$ for genistein. Prior chromatographic separation is required to discriminate between plant-derived and endogenous steroidal oestrogens. Coumestrol was present in the blood of goats $(2.0$ to $3.9 \mathrm{ng} / \mathrm{ml})$ after feeding alfalfa hay at a rate supplying $12 \mathrm{mg}$ coumestrol/24 hr/animal.
\end{abstract}

\section{INTRODUCTION}

The $105,000 \mathrm{~g}$ supernatant of uterine homogenates contains a macromolecular (8 to $9 \mathrm{~S}$ ) component that selectively binds oestrogenic steroids (Gorski, Toft, Shyamala, Smith \& Notides, 1968; Jensen, Suzuki, Numata, Smith \& DeSombre, 1969). This property of uterine cytosol preparations, derived either from 6-day-pregnant rabbits (Korenman, 1968; Corker \& Exley, 1970) or from ovariectomized ewes (Shutt, 1969) has been utilized for the development of a sensitive and specific competitive protein-binding assay for oestradiol-17 $\beta$.

The weak oestrogens, coumestrol and genistein (Text-fig. 1), found in high 
concentration in fungus-infected alfalfa, Medicago sativa (Loper \& Hanson, 1964; Bickoff, 1968; Shemesh, Lindner \& Ayalon, 1969) and in subterranean clover, Trifolium subterraneum L. (Bradbury \& White, 1954), respectively, mimic many but not all of the biological and biochemical actions of oestradiol-17 $\beta$ on the uterus (Noteboom \& Gorski, 1963; Perel \& Lindner, 1970). An examination of whether the oestrogenic properties of these non-steroidal substances were reflected by an ability to compete with oestradiol- $17 \beta$ for binding sites on the extranuclear uterine oestradiol receptor showed that this was, in fact, the case.

The occurrence of non-steroidal oestrogens in forage and pasture legumes often leads to infertility and disease of the urogenital system in sheep and cattle (Bennets, Underwood \& Shier, 1946; Adler \& Trainin, 1961; Moule, Braden \&<smiles>[R]Oc1ccc2c(c1)oc1c3ccc(O)cc3oc(=O)c21</smiles>

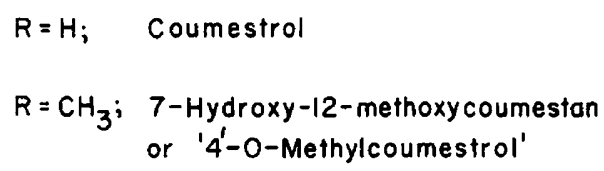<smiles>COc1cc2oc(=O)c3c4ccc(O)cc4oc3c2cc1O</smiles><smiles>CC(=O)OCOc1cc2cc3c(=O)oc4cc(O)ccc4c3oc-2c1</smiles><smiles>[R]Oc1ccc(C2=COC3=CC(O)=CC4=C2OCOC34)cc1</smiles>

$\mathrm{R}=\mathrm{H}$; Genistein

$\mathrm{R}=\mathrm{CH}_{3} ;$ Biochanin $-\mathrm{A}$

TEXT-FIG. 1. Structure of coumestan derivatives and isoflavones tested for competition with oestradiol-17 $\beta$ for binding sites on uterine receptor. (For literature, see Bickoff, 1968.)

Lamond, 1963; Thain, 1966; Bickoff, 1968). Progress in the investigation of the complex ecology of this syndrome depends on the availability of accurate methods for the determination of phyto-oestrogens in the blood of grazing animals. A number of such methods have been described (Lindner, 1967; Shutt, Axelsen \& Lindner, 1967). All these require large blood samples and a considerable amount of skilled technical work. The observation that the uterine oestradiol receptor will also bind non-steroidal phyto-oestrogens made it possible to develop a simple and sensitive competitive protein-binding radioassay for these substances in blood, suitable for the analysis of large numbers of samples. 


\section{MATERIALS AND METHODS}

Animals

Cross-bred rabbits were killed on the 6th day of pregnancy. The uteri were dissected out and used at once for preparation of the cytosol fraction (v.i.).

Six, virgin, 18-month-old goats of the Saanen breed were fed straw for 3 days before experimental feeding with alfalfa hay, offered without restriction for 24 $\mathrm{hr}$. The hay was mildly affected by a leaf-spotting organism (cf. Shemesh $e t$ al., 1969) and contained $24 \mu \mathrm{g}$ coumestrol/g dry matter by fluorometric assay following paper chromatographic separation (Lindner, 1967). Blood samples $(10 \mathrm{ml})$ were collected from the jugular vein onto heparin before feeding alfalfa, and at various time intervals while alfalfa was being consumed.

\section{Oestrogen-binding system}

The rabbit uteri were extracted according to the method described by Korenman (1968). Homogenization was carried out in 3 vol. of cold tris buffer $\left(0.01 \mathrm{~m}\right.$-tris- $\mathrm{HCl}, \mathrm{pH} 8.0$, containing $0.001 \mathrm{~m}$-EDTA and $0.25 \mathrm{~m}$-sucrose, $\left.4^{\circ} \mathrm{C}\right)$, using a Virtis blender with the tube immersed in crushed ice and applying five pulses of $15 \mathrm{sec}$ during $3 \mathrm{~min}$. The homogenate was centrifuged at $0^{\circ} \mathrm{C}$ for 15 $\mathrm{min}$ at $7000 \mathrm{~g}$ and the supernatant recentrifuged at $100,000 \mathrm{~g}$ for $90 \mathrm{~min}$. The soluble fraction (uterine 'cytosol') was divided into small portions $(2 \mathrm{ml})$ and these were stored at -50 to $-70^{\circ} \mathrm{C}$ until used in the radioassay. The preparation was stable for at least 1 month.

\section{Plasma extraction}

Solvents were of analytical reagent grade and were redistilled before use. One ml of plasma was extracted with 10 vol. ethylacetate/tetrahydrofuran (7:3) by mechanical shaking in glass-stoppered tubes for 20 min. After centrifugation for $10 \mathrm{~min}$ at $2500 \mathrm{rev} / \mathrm{min}$, the supernatant was taken to dryness under a gentle stream of nitrogen. The residue was subjected to thinlayer or paper chromatography.

This procedure is designed to extract 'free' coumestrol only. Further coumestrol - the water-soluble or 'conjugated' fraction-is extractable after enzymic hydrolysis (Shutt et al., 1967; Shutt, Braden \& Lindner, 1969).

\section{Chromatography}

Thin layer chromatography sheets (Eastman Chromatogram sheet type $\mathrm{K}$ 301 R.2 silica gel without fluorescent dye) were washed before use by overrunning with four solvents as recommended by Rosenfield, Eberlein \& Bongiovanni (1969), followed by a further wash with the solvent system (benzene/ ethylacetate, $1: 1$ ) to be used for development. The sheets were then dried at $80^{\circ} \mathrm{C}$ for $30 \mathrm{~min}$ and stored in a desiccator until required.

Paper chromatography was carried out on Whatman No. 1 chromatography paper prewashed by over-running with methanol for at least $25 \mathrm{hr}$ and with ethylacetate for at least $12 \mathrm{hr}$. Benzene :methanol : water, 10:5:5 (Lindner, 1967) was used for development. Coumestrol standards were detected by exposure to ultraviolet light, which induced a blue fluorescence. The corres- 
ponding areas of the lanes carrying plasma extracts were eluted with ethylacetate, and the solvent was removed at $45^{\circ} \mathrm{C}$ under a gentle stream of nitrogen.

\section{Competitive protein-binding assay}

Eluates of the coumestrol areas of thin layer or paper chromatograms carrying goat plasma extracts, or known amounts of pure coumestrol $(0.5$ to $50 \mathrm{ng}$ ), oestradiol $(0.01$ to $0.3 \mathrm{ng})$, genistein $(2.5$ to $200 \mathrm{ng})$, or related coumestan or isoflavone derivatives, were dried under nitrogen at $45^{\circ} \mathrm{G}$ in $4 \times 1 \mathrm{~cm}$ test tubes and redissolved in $0.2 \mathrm{ml}$ tris- $\mathrm{HCl}$ buffer containing 5600 counts $/ \mathrm{min}$ of $\left[6,7-{ }^{3} \mathrm{H}\right]$ oestradiol $-17 \beta$ (specific activity $48 \mathrm{Ci} / \mathrm{mmol}$; New England Nuclear Corporation). The tubes were shaken and left standing for $10 \mathrm{~min}$. Uterine cytosol (50 $\mu$ l per tube) was then added, the tubes were shaken again and incubated at $23^{\circ} \mathrm{C}$ for $30 \mathrm{~min}$. After this time, each tube received $1.1 \mathrm{ml}$ of a suspension of dextran-coated charcoal, composed of $0.5 \mathrm{~g}$ Norit A activated charcoal (No. N-6502, Sigma Chemical Co.) and $5 \mathrm{mg}$ dextran $\mathrm{T}_{40}$ (Pharmacia, Uppsala) in $200 \mathrm{ml} \mathrm{0.01}$ M-tris-HCl buffer of $\mathrm{pH} \mathrm{8.0} \mathrm{(Corker} \mathrm{\&} \mathrm{Exley,} \mathrm{1970).}$ The tubes were incubated at $4^{\circ} \mathrm{C}$ for $10 \mathrm{~min}$ and centrifuged for $10 \mathrm{~min}$ at $3000 \mathrm{rev} / \mathrm{min}$. One $\mathrm{ml}$ of the supernatant was withdrawn and then dissolved in Bray solution, and counted in a Packard model 3003 liquid scintillation spectrometer. Standard curves and unknowns were run in duplicate.

\section{RESULTS}

Displacement of $\left[{ }^{3} \mathrm{H}\right]$ oestradiol from uterine 'receptor' by phyto-oestrogens

Addition of coumestrol or genistein inhibited the uptake of $\left[{ }^{3} \mathrm{H}\right]$ oestradiol by the macromolecular binding agent in the cytosol fraction of the pregnant rabbit uterus (Text-fig. 2). Under the experimental conditions described, 50\% inhibition of the binding of radio-oestradiol was brought about by addition of approximately $0.2 \mathrm{ng}$ cold oestradiol, $14 \mathrm{ng}$ coumestrol or $35 \mathrm{ng}$ genistein. The degree of inhibition of $\left[{ }^{3} \mathrm{H}\right]$ oestradiol binding bore a near-linear relationship (Text-fig. 2) to the logarithm of the amount of phyto-oestrogen added over the range 0.5 to $40 \mathrm{ng}$ for coumestrol or 2.5 to $200 \mathrm{ng}$ for genistein, though the slope of the coumestrol curve was slightly flatter below $4 \mathrm{ng}$.

When added in amounts up to $200 \mathrm{ng}, 4^{\prime}$-O-methylgenistein ('biochanin-A', Text-fig. 1), formononetin (7-hydroxy-4'-methoxyisoflavone), 12-O-methylcoumestrol, sativol and medicagol (Text-fig. 1) did not inhibit significantly the binding of $\left[{ }^{3} \mathrm{H}\right]$ oestradiol in this system.

\section{Competitive protein-binding assay for plasma coumestrol}

Extracts of $1.0 \mathrm{ml}$ peripheral plasma of six goats fed straw and concentrates were fractionated by thin-layer or paper chromatography and eluates from the coumestrol areas were subjected to the competitive protein-binding assay. No coumestrol was detected ( $<0.5 \mathrm{ng} /$ eluate). When coumestrol ( 1 to $10 \mathrm{ng} / \mathrm{ml}$ ) was added to this plasma, all the extracts examined (16/16) inhibited the binding of $\left[{ }^{3} \mathrm{H}\right]$ oestradiol by the uterine cytosol preparation. The recovery of added coumestrol, as determined by competitive protein-binding assay following chromatography, was $49 \cdot 5 \% \pm 2 \cdot 6$ S.E. and did not differ significantly 


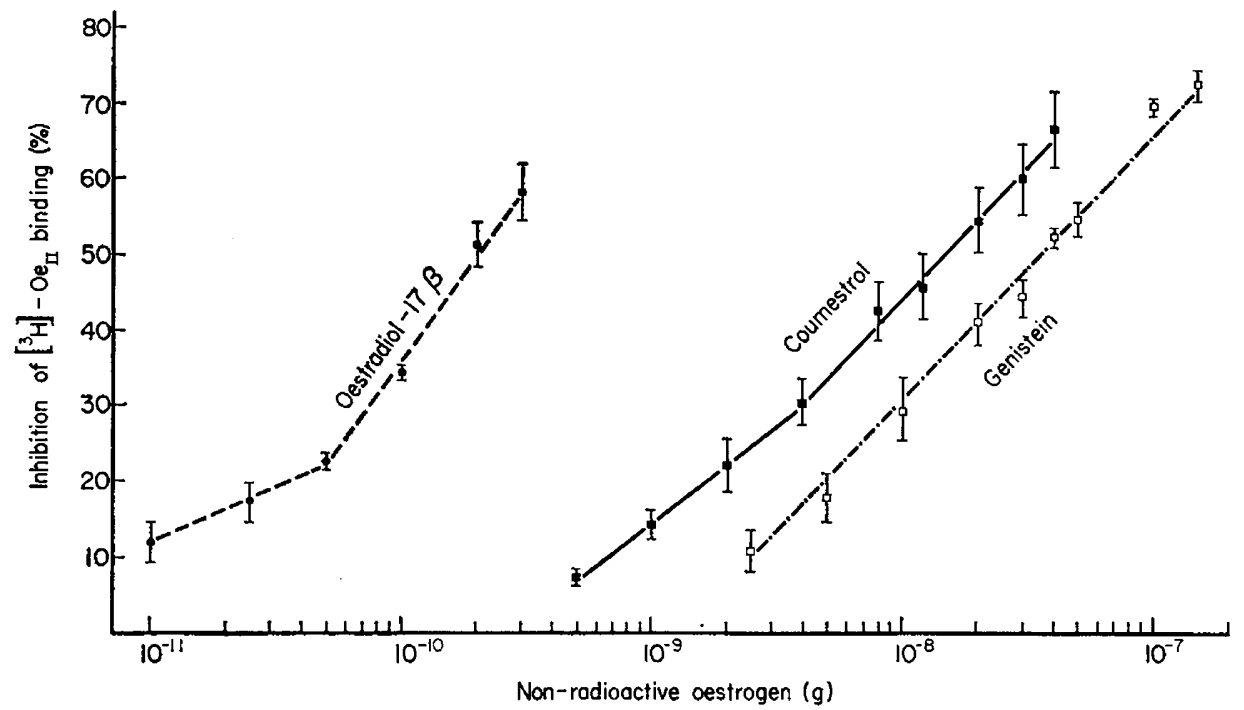

TexT-FIc. 2. Inhibition of binding of $\left[{ }^{3} \mathrm{H}\right]$ oestradiol-17 $\beta$ to uterine cytosol fraction by cold oestradiol-17 $\beta$ and by two non-steroidal oestrogens. (The unbound fraction was separated by dextran-coated charcoal at $4^{\circ} \mathrm{G}$.) Vertical brackets indicate \pm S.E.

between samples analysed by thin-layer or by paper chromatography. Accordingly, all plasma assay results were corrected for $50 \%$ losses during analysis.

During the feeding of alfalfa hay, the free plasma coumestrol level in the six goats rose from an undetectable level ( $<\mathrm{lng} / \mathrm{ml}$ ) to $2 \cdot 0 \mathrm{to} 3.9 \mathrm{ng} / \mathrm{ml}$ (Table 1). The rise was apparent within $2 \mathrm{hr}$ of offering alfalfa. At this time, the mean intake of coumestrol was $7.6 \mathrm{mg} / \mathrm{goat}$. The total intake was $12 \mathrm{mg}$ coumestrol/ $24 \mathrm{hr} /$ goat.

Table 1

PLASMA GOUMESTROL LEVELS IN GOATS DURING FEEDING OF ALFALFA HAY

\begin{tabular}{|c|c|c|c|}
\hline \multirow{2}{*}{$\begin{array}{l}\text { Duration of } \\
\text { alfalfa feeding } \\
\text { (hr) }\end{array}$} & \multicolumn{2}{|c|}{ Cumulative intake per goat } & \multirow{2}{*}{$\begin{array}{c}\text { Plasma } \\
\text { coumestrol } \uparrow \\
(\mathrm{ng} / \mathrm{ml})\end{array}$} \\
\hline & Hay $(g)$ & Coumestrol* (mg) & \\
\hline $\begin{array}{r}0 \\
2 \\
4 \\
6 \\
24\end{array}$ & $\begin{array}{r}0 \\
400 \\
450 \\
(>450) \\
652\end{array}$ & $\begin{array}{c}0 \\
7 \cdot 6 \\
8 \cdot 6 \\
(>8 \cdot 6) \\
12 \cdot 0\end{array}$ & $\begin{array}{r}<1.0 \\
2.0 \\
3.7 \\
3.9 \\
2.4\end{array}$ \\
\hline
\end{tabular}

* The hay contained $24 \mu \mathrm{g}$ coumestrol/g dry matter by fluorimetric assay following paper chromatography (Lindner, 1967).

$\dagger$ Unconjugated coumestrol in pooled plasma from six goats by competitive protein-binding assay following thinlayer chromatography (mean of duplicate determinations). 


\section{DISGUSSION}

The experiments described established that the weak non-steroidal oestrogens, coumestrol and genistein, are able to compete with oestradiol for binding sites on a macromolecular component of the uterine cytosol. Evidently, a steroid skeleton is not a prerequisite for such binding. The affinity of the cytoplasmic oestrogen 'receptor' for diethylstilboestrol even exceeds that for oestradiol (Korenman, 1969).

In general, the affinity of this receptor for various ligands is related to their oestrogenic potency but there are exceptions to this rule; in particular, antioestrogens may also be tightly bound (Toft \& Gorski, 1966; Korenman, 1969; Korenman, Tulchinsky \& Eaton, 1970). In uterine weight assays, coumestrol is about 160 times less potent than oestradiol-17 $\beta$, but 15 to 100 times more potent than genistein, depending on species and route of administration (Braden, Hart \& Lamberton, 1967; Bickoff, 1968; Perel \& Lindner, 1970). The relative binding affinity of the receptor, as defined by Korenman (1969), is roughly 70 times lower for coumestrol, and 175 times lower for genistein, than for oestradiol-17 $\beta$ (Text-fig. 2). Thus, the affinity of the receptor for these ligands appears related to their uterotrophic potency, though the difference between coumestrol and genistein in binding affinity is rather less than might be expected from their relative biological activity. The greater affinity of the receptor for coumestrol, compared with genistein, is probably attributable to the fact that the ring system of coumestrol is held rigidly in one plane, thus approximating to the shape of oestradiol, whereas one of the phenolic rings of genistein is free to rotate.

Coumestrol and genistein mimic the action of oestradiol on the uterus with respect to water imbibition, vascular permeability, and incorporation of labelled precursors into RNA, protein and phospholipid (Noteboom \& Gorski, 1963; Perel \& Lindner, 1970), and they are now shown to resemble oestradiol also in interacting with the uterine oestrogen receptor. However, neither compound is able to mimic, or inhibit, the ovum-implantation-inducing action of oestradiol in the lactating or progesterone-treated ovariectomized rat (Perel \& Lindner, 1970 ), suggesting that the latter action of oestradiol may not be mediated by the same uterine receptor.

Both coumestrol and genistein have two phenolic hydroxyl groups at opposite poles of the molecule, and the distance between these is similar to that between the 3- and 17-hydroxyl groups of oestradiol-17 $\beta$. Both hydroxyl groups seem essential for strong binding to the uterine oestrogen receptor. This is shown by the behaviour of sativol (Text-fig. 1), a coumestan in which the 7-OH group is masked, and the behaviour of 12-O-methylcoumestrol, medicagol, biochanin-A and formononetin, in which the OH-group in position 12 (i.e. 4' of the alternative nomenclature) is masked: none of these compounds effectively competed with oestradiol-17 $\beta$ for receptor sites. Methoxy-coumestans and isoflavones such as 12-O-methylcoumestrol and biochanin-A should probably be regarded as pro-oestrogens, as defined by Emmens (1941), since, though themselves unable to interact with the uterine oestrogen receptor, they readily undergo O-demethylation in vivo to form the active oestrogens, coumestrol 
and genistein, respectively (Nilsson, 1961; Lindner, 1967; Shutt et al., 1967, 1969; Adler \& Weitzkin-Neiman, 1970). O-demethylation of 12-O-methylcoumestrol was recently observed on incubation of this compound with bovine liver homogenates (Shemesh \& Lindner, unpublished results). Formononetin is susceptible to further reductive metabolism in ruminants to the weak oestrogen, equol (Braden et al., 1967; Shutt et al., 1967).

Terenius (1967) reported that certain oestrogenic derivatives of doisynolic and allenoic acid inhibited the uptake of oestradiol by surviving mouse uterus, but their 7-methyl ethers did not. Likewise, Korenman (1969) showed that the affinity of the uterine cytosol receptor is low for the $17 \beta$-acetate and even lower for the 3-methyl ether of oestradiol-17 $\beta$, stressing the importance of the two hydroxyl groups in the binding process. The divergent observation by Korenman (1969) of highly effective binding of the 3-acetates of oestrone and oestradiol by the receptor is probably attributable, in our opinion, to hydrolysis of these labile esters under the conditions of the assay used.

The ability of coumestrol to inhibit the uptake of $\left[{ }^{3} \mathrm{H}\right]$ oestradiol by a uterine receptor preparation was exploited by us to devise a rapid assay of this phyto-oestrogen in blood. The assay is even more sensitive than the methods previously described (Lindner, 1967), which made use of fluorimetry or gaschromatography with hydrogen-flame-ionization detection. The new assay is less laborious. It should be equally applicable to genistein and possibly to other isoflavones. The sensitivity of the assay for these compounds should be slightly less than for coumestrol, but may be enhanced by using $\left[{ }^{3} \mathrm{H}\right]$ oestriol (estriol specific activity $50 \mathrm{Ci} / \mathrm{mmol}$-New England Nuclear Corporation catalogue $1970 / 71$ ) instead of $\left[{ }^{3} \mathrm{H}\right]$ oestradiol- $17 \beta$ as the competing labelled ligand.

Coumestrol could be detected in the plasma of goats $(2.0$ to $3.9 \mathrm{ng} / \mathrm{ml})$ on a relatively low intake of coumestrol $(12 \mathrm{mg} / 24 \mathrm{hr}$ ). It should be noted that the 12-O-methylcoumestrol content of the hay fed was not determined and this may have contributed to the plasma coumestrol level (Shutt et al., 1969; Shemesh et al., 1969). Shutt et al. (1969), using a fluorimetric assay (Lindner, 1967), found plasma levels of 5 to $7 \mathrm{ng} / \mathrm{ml}$ free coumestrol in sheep consuming medic hay (Medicago littoralis). The estimated daily intake of phyto-oestrogens was $146 \mathrm{mg}$ coumestrol and $124 \mathrm{mg}$ 12-O-methylcoumestrol. Marinov, WeitzkinNeiman \& Adler (1969), using a similar method, were able to detect $1.21 \mathrm{ng} / \mathrm{ml}$ free coumestrol in a pooled plasma sample from cows fed concentrates containing alfalfa meal, at a rate supplying approximately $0.4 \mathrm{mg}$ dietary coumestrol/cow/day.

The competitive protein-binding assay technique will not measure the blood level of methylated pro-oestrogens, such as 12-O-methylcoumestrol, biochanin-A and formononetin. The latter compound may be particularly significant in the aetiology of the infertility syndrome on subterranean clover pastures (Millington, Francis \& McKeown, 1964). A chromatographic step before the competitive protein-binding assay is required to discriminate between phyto-oestrogens and endogenous steroidal oestrogens.

An alternative approach to the rapid and sensitive determination of phytooestrogens in blood has been suggested (Bauminger, Lindner, Perel \& Arnon, 1969; Lindner, Perel \& Friedlander, 1971), based on a radioimmunoassay. 
Antibodies to genistein and coumestrol have been prepared. It remains to be seen which approach will prove more useful. Interestingly, antibodies to phyto-oestrogens did not cross-react with oestradiol, indicating that the recognition of oestrogens by antibody and receptor protein depends on different features of the ligand molecule.

\section{ACKNOWLEDGMENTS}

We are grateful to Dr E. M. Bickoff for his kindness in providing us with the coumestan derivatives used in this study, to Dr C. S. Corker for helpful advice, to Miss Anita Glickman for skilled technical assistance, and to the Ford Foundation (Grant No M65-I43 to H.R.L.) for generous financial support. This work was submitted by M.S. in partial fulfilment of the requirement for the $\mathrm{Ph} . \mathrm{D}$. degree at the Weizmann Institute's Graduate School.

\section{REFERENCES}

AdLER, J. H. \& TRAin, D. (1961) The apparent effect of alfalfa on the reproductive performance of dairy cattle. Proc. IVth Int. Congr. Anim. Reprod. 3, 451.

Adler, J. H. \& Weitzkin-Neiman, G. (1970) Demethylation of methyl-O-coumestrols by rumen microorganisms in vitro. Refuah vet. 27, 51 .

Bauminger, S., Lindner, H. R., Perel, E. \& Arnon, R. (1969) Antibodies to a phyto-oestrogen: antigenicity of genistein coupled to a synthetic polypeptide. F. Endocr. 44, 567.

BenNetTs, H. W., Underwood, E. J. \& ShIER, F. L. (1946) A specific breeding problem of sheep on subterranean clover pastures in Western Australia. Aust. vet. F. 22, 2.

Bickorf, E. M. (1968) Oestrogenic constituents of forage plants. Commonw. agric. Bur. Rev. series 1, 1.

BradeuRy, R. B. \& White, E. E. (1954) Estrogens and related substances in plants. Vitams Horm. 12, 207.

Braden, A. W. H., Hart, N. K. \& Lamberton, J. A. (1967) The oestrogenic activity and metabolism of certain isoflavones in sheep. Aust. J. agric. Res. 18, 335.

CoRker, C. S. \& ExLEY, D. (1970) The determination of plasma estradiol-17 $\beta$ by competitive protein binding radioassay. Steroids, $15,469$.

Emmens, C. W. (1941) Precursors of oestrogens. F. Endocr. 2, 444.

Gorski, J., Toft, D., Shyamala, G., Smith, D. \& Notides, A. (1968) Hormone receptors: studies on the interaction of estrogen with the uterus. Recent Progr. Horm. Res. 24, 45.

Jensen, E. V., Suzuki, T., Numata, M., Smith, S. \& DeSombre, E. R. (1969) Estrogen-binding substances of target tissues. Steroids, 13, 417.

Korenman, S. G. (1968) Radio-ligand binding assay of specific estrogens using a soluble uterine macromolecule. 7. clin. Endocr. 28, 127.

Korenman, S. G. (1969) Comparative binding affinity of estrogens and its relation to estrogenic potency. Steroids, 13, 163.

Korenman, S. G., TulChinsky, D. \& Eaton, L. W., JR (1970) Radio-ligand binding procedures for estrogen assay in normal and pregnancy plasma. In: Steroid Assay by Protein Binding, 2nd Karolinska Symposia on Research Methods in Reproductive Endocrinology, Geneva 1970, p. 291. Ed. E. Diczfalusy.

LindNER, H. R. (1967) Study of the fate of phyto-oestrogens in the sheep by determination of isoflavones and coumestrol in the plasma and adipose tissue. Aust. F. agric. Res. 18, 305.

Lindner, H. R., Pered, E. \& Friedlander, A. (1971) Antibodies to oestrogens. In: Research on Steroids, Vol. IV, IIIrd Int. Study Group for Steroid Hormones, Rome, 1969, p. 199. Eds. M. Finkelstein, A. Klopper, C. Conti and C. Cassano. Pergamon Press, Oxford.

LOPER, G. M. \& HANSON, G. H. (1964) Influence of controlled environmental factors and two foliar pathogens on coumestrol in alfalfa. Crop Sci. 4, 480.

Marinov, U., Weitzkin-Netman, G. \& Adler, J. H. (1969) Identification of coumestrol in bovine blood. Refuah vet. 26, 7.

Millington, A. J., Francis, G. M. \& MaKeown, N. R. (1964) Wether bioassay of annual pasture legumes. II. The oestrogenic activity of nine strains of Trifolium subterraneum L. Aust. $\mathcal{F}$. agric. Res. 15, 527.

Moule, G. R., BRAden, A. W. H. \& Lamond, D. R. (1963) The significance of oestrogens in pasture plants in relation to animal production. Anim. Breed. Abstr. 31, 139. 
Nirsson, A. (1961) On the in vitro metabolism of the plant oestrogen Biochanin A in rumen fluid. Ark. Kemi $, 17,305$.

Nотевоом, W. D. \& GoRski, J. (1963) Estrogenic effect of genistein and coumestrol diacetate. Endocrinology, 73, 736.

Perel, E. \& LindNer, H. R. (1970) Dissociation of uterotrophic action from implantation-inducing activity in two non-steriodal oestrogens (coumestrol and genistein). F. Reprod. Fert. 21, 171.

Rosenfield, R. L., Eberlein, W. R. \& Bongiovanni, A. M. (1969) Measurement of plasma testosterone by means of competitive protein binding analysis. F. clin. Endocr. 29, 854.

Shemesh, M., Lindner, H. R. \& Ayalon, N. (1969) Coumestrol and 4'-O-methyl-coumestrol in alfalfa grown in Northern Israel: possible effect of a foliar pathogen (Pseudopeziza medicaginis [Lib.]). Refuah vet. 26, 1.

SHuTt, D. A. (1969) Measurement of estradiol-17 $\beta$ in plasma by competitive protein-binding radioassay. Steroids, 13, 69.

Shutt, D. A., Axelsen, A. \& Lindner, H. R. (1967) Free and conjugated isoflavones in the plasma of sheep following ingestion of oestrogenic clover. Aust. J. agric. Res. 18, 647.

Shutt, D. A., Braden, A. W. H. \& Lindner, H. R. (1969) Plasma coumestrol levels in sheep following administration of synthetic coumestrol or ingestion of medic hay (Medicago littoralis). Aust. $\mathcal{J}$. agric. Res. 20, 65.

TERENIUS, L. (1967) Inhibition of $17 \beta$-oestradiol uptake in mouse uterus by diosynolic and allenoic acid derivatives: an in vitro differentiation between true oestrogens and pro-oestrogens. Acta pharmac. tox. 25, 313.

Thain, R. I. (1966) Evidence for the widespread involvement of clover pastures in bovine infertility in Tasmania. Aust. F. Sci. 29, 220.

TofT, D. \& Gorski, J. (1966) A receptor molecule for estrogens: isolation from the rat uterus and preliminary characterization. Proc. natn. Acad. Sci. U.S.A. 55, 1574. 